\title{
Применение кластерного подхода для развития отраслей сельского хозяйства Республики Саха (Якутия)
}

\author{
Васильев Н.П., магистрант, \\ Северо-Восточный федеральный университет, \\ 2. Якутск \\ E-mail: deathmufc@mail.ru
}

Научный руководитель: д.э.н., профессор Данилова Л.И.

На данный момент, в условиях импортозамещения, задача обеспечения населения местной экологически чистой продукцией стало актуальной как никогда, особенно в тех регионах Российской Федерации, которые имеют проблемы в производстве сельскохозяйственной и иной продукции. Рассмотрим данную проблему на примере одного из важнейших отраслей сельского хозяйства России картофелеводства.

На сегодняшний день, картофелеводство занимает ведущие позиции в структуре сельского хозяйства России. По разным источникам Российская Федерация занимает 2е место по объему производства, уступая лишь Китаю. Среднее потребление картофеля на душу населения составляет 120-130 кг в год на человека, а рациональная норма потребления данного продукта является 90 кг в год на человека [1]. В 2015 году валовые сборы достигли отметки 33,6 млн. тонн, что учитывая рациональную норму потребления, удовлетворенность населения картофелем произведенного в России составило 255,2\%.

Исходя из этих данных, можно сделать вывод, что производимый в России картофель статистически удовлетворяет нормативные потребности населения в этом продукте, но, несмотря на это, в отдельных регионах существует такая проблема, как нехватка картофеля местного производства. Эти субъекты не удовлетворяют нормативные потребности своего населения в картофеле, из-за чего импортируют его из зарубежных стран.

Одним из таких субъектов является Республика Саха (Якутия), которая славится не только своими природными ресурсами, но и особыми природно-климатическими условиями, из-за которых страдает отрасль сельского хозяйства, но также и другие отрасли экономики.

Валовые сборы картофеля в республике в 2015 году составили 71,95 тыс. тонн. Нормативная удовлетворенность населения составляет 83,5\%, что ниже показателя по России более чем в 3 раза.

Если учесть то, что Россия, имея выдающиеся показатели среднего потребления на душу населения и нормативной удовлетворенности населения, не может полностью обеспечить свое население картофелем местного производства, показатель Якутии и вовсе станут мизерными. Как и в стране, республика показывает относительно хорошие результаты благодаря некоторым муниципальным образованиям, которые, как и некоторые субъекты показывают выдающиеся результаты, за счет которых правятся показатели.

Из 36 муниципальных образований Якутии, удовлетворяют нормативные потребности населения - 11 муниципальных районов, муниципальные образования, в 
которых удовлетворенность составляет $90 \%$ и более - 3, в том числе ГО «Жатай», а остальные 22 муниципальных образований, в том числе ГО «Г. Якутск», не удовлетворяют нормативные потребности своего населения.

Лучшие результаты по валовым сборам показывают:

Таблица 1

Муниципальные образования с лучшими показателями валовых сборов на 2015г.

и их нормативная удовлетворенность населения

\begin{tabular}{|l|l|c|c|}
\hline$№$ & Муниципальное образование & $\begin{array}{l}\text { Валовые сборы } \\
\text { (центнер) }\end{array}$ & $\begin{array}{l}\text { Нормативная удовлетворенность } \\
\text { населения (в процентах) }\end{array}$ \\
\hline 1 & Олекминский район & 115434,8 & $506 \%$ \\
\hline 2 & Городской округ «Город Якутск» & 87226 & $30 \%$ \\
\hline 3 & Ленский район & 79722,8 & $235 \%$ \\
\hline 4 & Хангаласский улус & 68591,9 & $166 \%$ \\
\hline 5 & Мегино-Кангаласский улус & 45875,7 & $236 \%$ \\
\hline
\end{tabular}

Исходя из таблицы 1 , можно заметить, что кроме ГО «Г. Якутск», остальные муниципальные образования удовлетворяют нормативные потребности своего населения в полной мере. Столица республики в данном списке имеет самую маленькую территорию и является самым густонаселенным муниципальным образованием. В Якутске живет больше 30\% от общего числа населения Якутии, из-за чего город является самым нуждающимся муниципальным образованием, с нехваткой более 20 тыс. тонн для нормативного удовлетворения населения картофелем собственного производства, но учитывая ее территорию это невозможно.

Следует поставить задачу обеспечения столицы за счет близлежащих районов, в которых население удовлетворено картофелем собственного производства и имеет излишки, которые можно сбыть.

Город Якутск граничит всего с 5 муниципальными образованиями, из которых удовлетворяют нормативные потребности своего населения только три, МегиноКангаласский улус, Хангаласский улус и Намский улус. Хангаласский и Намский улусы имеют круглогодичную доступность через автодороги, а доступность МегиноКангаласского улуса усложнена, речной переправой, особенно осенью и весной.

Теоретически, при условии суммирования валовых сборов данных улусов не хватит на удовлетворение нормативной потребности населения Городского округа «г. Якутск». Следует еще учитывать то, что помимо столицы республики существуют другие муниципальные образования, которые также не могут обеспечить себя, в частности Арктические и отнесенные к ним улусы.

Исходя из этого, мы пришли к выводу, что будет целесообразным создание на территории республики на 4 сельскохозяйственных кластера. Первый кластер «Обеспечивающий кластер», который будет состоять из 20 муниципальных образований, второй «Арктический кластер» - 14 муниципальных образований, третий - «Столичный кластер» - ГО «г. Якутск» и четвертый - «Нерюнгринский кластер» Нерюнгринский район.

Первый кластер, в соответствии со своим названием, будет обеспечивать другие. Кластер будет состоять из преимущественно тех муниципальных образований, которые удовлетворяют нормативные потребности своего населения. На территории будут проводиться основные мероприятия по развитию картофелеводства и растениеводства, в целом, за исключением материально-технической базы, то есть, картофелехранилищ и овощехранилищ, которые должны быть в каждом муниципальном образовании. 
Таблица 2

Общие сведения кластеров

\begin{tabular}{|l|l|l|l|l|l|}
\hline № & Показатели (на 2015 год) & Обеспечивающий & Арктический & Столичный & Нерюнгринский \\
\hline 1 & Территория (тыс. км²) & 1316,9 & 1570,1 & 3,6 & 93,0 \\
\hline 2 & Посевные площади (га) & 6551 & 275,1 & 1284,6 & 478 \\
\hline 3 & Население (человек) & 485830 & 77385 & 320595 & 75973 \\
\hline 4 & Валовые сборы (центнер) & 599326,9 & 20523,6 & 87226 & 12152 \\
\hline 5 & Удовлетворенность (\%) & $137 \%$ & $29 \%$ & $30 \%$ & $18 \%$ \\
\hline 6 & Нехватка (тонн) & -16208 & 4912,3 & 20131 & 5622,4 \\
\hline
\end{tabular}

Соответственно, второй, третий и четвертый кластер будут обеспечиваемыми, в силу своих территориальных, природно-климатических и иных особенностей, которые не позволяют обеспечить свое население.

Благодаря расположению и сосредоточению «Обеспечивающего кластера» в центре республики, обеспечивать остальные будет легче так, как он граничит со всеми кластерами.

Преимущества создания кластеров: образований;

- повышение конкуренции среди «обеспечивающих» муниципальных

- дополнительный доход для населения и сельхозтоваропроизводителей;

- упрощение обеспечения северных районов;

- рациональное распределение и использование средств, выделенных на поддержку растениеводства;

- улучшение взаимодействия между муниципальными образованиями.

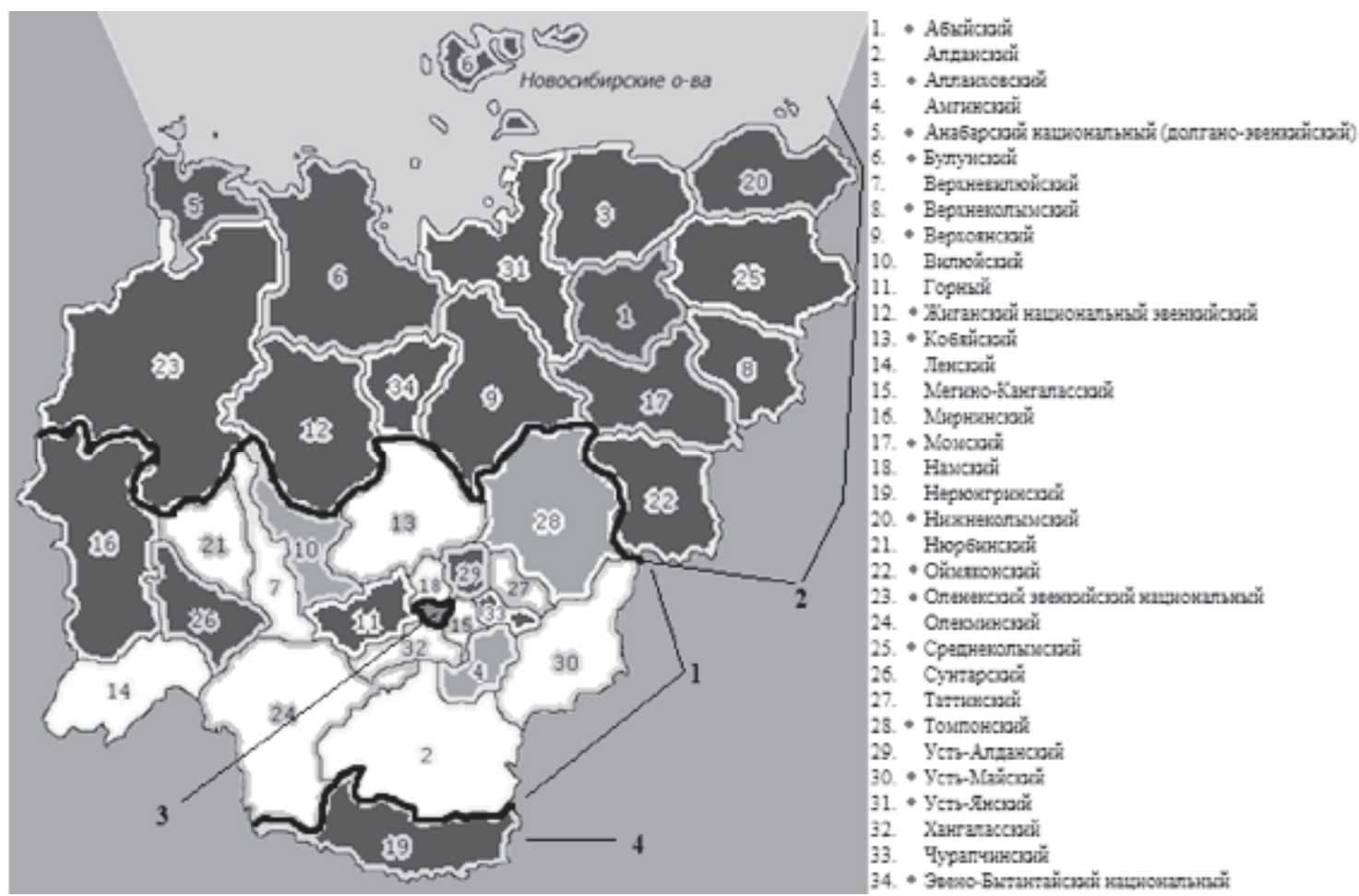

Рис. 2. Кластерное разделение Республики Саха (Якутия).

1 - «Обеспечивающий кластер», 2 - «Арктический кластер», 3 - «Столичный кластер», 4 - «Нерюнгринский кластер» 
При условии успешной реализации подобной кластеризации, у республики появится возможность обеспечить свое население местной экологически чистой продукцией и отказаться от импорта товарного картофеля, чтобы оставить только импорт семенного картофеля. Данное разделение может быть применимо не только по отношению к картофелю, но и другой сельскохозяйственной продукции, в частности продукции растениеводства.

На территории муниципальных образований республики должны появиться конкурентоспособные хозяйства, которые будут конкурировать между собой качеством, количеством и ассортиментом своей продукции. Это должно поспособствовать появлению брендов, для роста их дохода и дополнительного дохода для населения, которое будет сотрудничать с хозяйствами в различных аспектах. Появится конкуренция в исполнении государственных контрактов на поставку сельхозпродукции в Арктические районы. Это в целом, должно поспособствовать урегулированию цен на сельскохозяйственную продукцию местного производства и сделать приемлемыми для всего населения.

\section{Список литературы:}

1. Приказ Министерства здравоохранения Российской Федерации от 19 августа 2016 г. №614 «Об утверждении рекомендаций по рациональным нормам потребления пищевых продуктов, отвечающих современным требованиям здорового питания» [Электронный ресурс].- Код доступа: http://www.nalogplan.ru/npddoc?docId=268818\&modId=97

2. Официальный сайт Федеральной службы государственной статистики Федерации [Электронный ресурс]. Код доступа: http://www.gks.ru/

3. Официальный информационный портал Республики Саха (Якутия) [Электронный ресурс]. - Код доступа: https://www.sakha.gov.ru/

\section{Жертвоприношение в структуре обрядов жизненного цикла}

\section{Васильева О.Д., студентка, Северо-Восточный федеральный университет, 2. Якутск \\ E-mail: vasiliewa.vasilek@mail.ru}

Научный руководитель: к.и.н., доцент Яковлева К.М.

Обряды жизненного цикла представляют собой определенные действия людей, при переходе от одного статуса в другое. Каждый обряд имеет свои неписаные нормы, правила, которые обязательны для каждого человека. Людям часто приходилось совершать ритуал жертвоприношения в дар духам, предкам, божествам. Кульминацией обрядового действия является акт жертвоприношения, а сам ритуал дает смысл и содержание.

Основными источниками являются полевой и архивные материалы. Среди жителей с. Балыктаха Мегино-Кангаласского улуса в 2015 году, было проведено исследование, методом полевых экспедиций. Применялось анкетирование, глубинное 